\section{Effectiveness of binahong leaves extract, soursop leaves extract and combination of binahong leaves and soursop leaves extract on hemostasis in cuts of mice}

\author{
Bismi M. Haris*, Hasmawati Hasan
}

laboratory experiment with post-test only with control group design. First stage involved the making of binahong and soursoup leaves extracts using maceration techniques. Male mice were adapted for seven days. Treatment on day 8 included cutting the tail measuring as much as $1 \mathrm{~cm}$ in the length from the tip of the tail. Bleeding time is calculated after dipping the tip of tail into the extract for 5 seconds until there was no blood dripping on gauze pads. Data were analyzed using Kruskal-Wallis test followed by Mann-Whitney U test.

Results: Binahong leaves extract, soursop leaves extract and combination of binahong and soursop leaves extracts affected hemostasis on cuts of male mice (mus musculus).

Conclusion: Combination of binahong and soursop leaves extracts has the best effectiveness.
Department of Oral and Maxillofacial Surgery, Faculty of Dentistry, Hasanuddin University, Makassar, Indonesia
*Corresponding to: Bismi M. Haris, Department of Oral and Maxillofacial Surgery, Faculty of Dentistry, Hasanuddin University, Makassar, Indonesia bismimagfirah11795@gmail.com

Received: 15 April 2017 Revised: 8 November 2017 Accepted: 9 November 2017 Available online: 1 December 2017

Keywords: Binahong leaves extract, Hemostasis, Soursop leaves extract

Cite this Article: Haris BM, Hasan H. 2017. Effectiveness of binahong leaves extract, soursop leaves extract and combination of binahong leaves and soursop leaves extract on hemostasis in cuts of mice. Journal of Dentomaxillofacial Science 2(3): 176-179. D0I: 10.15562/jdmfs.v2i3.465

\section{Introduction}

Tooth extraction is a common dental treatment. ${ }^{1}$ It is a process of removing a tooth from the alveolar process that will always cause tissue damage, both hard tissue and soft tissue, including damages such as bleeding, pain and edema. ${ }^{2}$ Tooth extraction is a common practice in dentistry. In Indonesia, the utilization of dental and oral healthcare for tooth extraction is very high at $79.6 \%$. Tooth extraction will leave the tooth socket and cause wound around soft tissue. Wound healing is affected by the ability of cells and tissue regeneration or return to the normal structure through cell growth. ${ }^{3}$

Bleeding is the most common complication, which usually occurs as a result of higher pressure in the blood vessels than outside the blood vessel. Normal bleeding occurs at extraction, but if it does not stop for 30-60 minutes then the operator must provide treatment to prevent excessive blood loss. Attempt is generally used to prevent bleeding is by applying pressure around the socket after extraction, by biting sponge or gauze placed over the extraction wound for 30 minutes. ${ }^{4}$
Process of the body to deal with the blood loss is called hemostasis; ${ }^{5}$ blood serves for oxygen circulation, distributing nutrients to all parts of the body, and as the body's defense against infections. ${ }^{5}$ Hemostasis system reflects the balance between procoagulant and anticoagulant mechanisms. The five major components involved here are platelets, coagulant factors, coagulation inhibitors, fibronolisis and blood vessels. ${ }^{6}$ The drugs used in the pharmacotherapy to accelerate blood clotting (hemostatic) is epinephrine as a vasoconstrictor, or treneksamat acid as antifibrinolitic material. ${ }^{7}$

Binahong plant is a potential medicinal plant that can cope with various kinds of diseases. One part of Binahong plant that is useful as a drug is its leaves. It contains flavonoids, terpenoids, essential oils, tannins and ascorbic acid. ${ }^{3}$ Soursop or annona muricata 1 . is one kind of plant from family Annonaceae that has spread in Indonesia and is the traditional medicine that has multiple benefits. Within the past few years, the soursop leaves have begun to be widely used as herbal medicine for treating some diseases. Indonesian society usually 
use the juice of soursop leaves as herbal remedy, which is prepared by boiling the leaves using fresh water. ${ }^{8}$ Soursop leaves contain flavonoids, triterpenoids, saponins, polyphenols, tannins and other secondary metabolites. Phytochemical contents of annonaceous acetogenin in soursop leaves extract act as active antibacterial agents. Soursop leaves are able to treat infections caused by bacteria, such as diarrhea, ulcers, urinary tract infections and upper respiratory tract infection. ${ }^{9,10}$ Tannin in the leaves can increase resistance to infection and useful in the maintenance of the mucous membranes. It also accelerates the cessation of bleeding process and promotes wound healing. ${ }^{7}$

The purpose of this study is to determine the effectiveness of binahong leaves extract, soursop leaves and combination of binahong and soursop leaves extract on the hemostasis process in cuts of mice.

\section{Material and methods}

This is an experimental laboratory-based research with post-test only and control group design. It was conducted in Entomology Laboratory, Faculty of Medicine Phytochemistry Laboratory Faculty of Pharmacy Hasanuddin University during November-December 2016. The sample used as the object of study was male mice (mus musculus). The formula used in the study was Frederer formula: $t(n-1) \geq 15 ; 3(n-1) \geq 15 ; 3 n$ $-3 \geq 15 ; n-1 \geq 15 ; n \geq 16$, explanation: $t-$ number of groups; $n-$ number of samples in each groups.

Based on the calculation of Frederer formula, each groups were allotted 6 mice, but in this research we used 10 animals for each group to get more accurate results. The total sample required for four groups during the study were 40 male mice. Inclusion criteria are male mice, healthy, age 2-4 months, no ring pattern in tails. Mice were adapted to new environment. Feeding is 3 times/day with pellets (food mice). Adaptation of the mice was carried out for 5 days. Fabrication of binahong

\section{Tabel 1 Bleeding time data, and the mean and standard deviations for each group}

\begin{tabular}{lcc}
\hline Treatment groups & \\
\hline & Bleeding time (Mean \pm SD) & $\boldsymbol{p}$ Value \\
Binahong leaves & $65.70 \pm 20.61$ \\
Soursop leaves & $75.50 \pm 32.48$ \\
Combination of binahong and soupsop & $46.59 \pm 19.70$ \\
leaves & \\
Distilled water (control) & $222.97 \pm 48.84$
\end{tabular}

"Kruskal-Wallis test; $p<0.05$; significant leaves extract and soursop leaves extract using maceration technique.

Male mice that were ready for experiment were removed from the cage. Alcohol paper was applied to their tails for anesthetic effect. Cutting of mice tail was done with surgical scissors, cutting a portion of about $5 \mathrm{~mm}$ from the tip of the tail. The cut portion of the tail was immersed in binahong leaves extract for 5 seconds. The stopwatch started immediately after cutting, until the blood stopped dripping on the absorbent paper (the wound should not touch absorbent paper). The stopwatch was stopped when there was no longer any blood on the absorbent paper and the time at that point was recorded. For the next group, the same procedure was repeated for the other 3 groups: treatment group using soursop leaves extract (group 2), combination of binahong leaves and soursop leaves extract (group 3), and the control group using distilled water (group 4). Data were collected from the recorded time of stopping of bleeding in each treatment group. Statistical analysis using Kruskal-Wallis test was carried out to see the differences between each group.

\section{Results}

This study used 40 male mice as samples, which were divided into four groups, and each group had 10 male mice. Bleeding time data of each group was recorded, and the mean was calculated. Mean and standard deviation of each group are shown in table 1.

Table 1 shows the mean bleeding time; binahong leaves extract showed $65.70 \pm 20.6$ seconds; soursop leaves extract group, $75.50 \pm 32.48$ seconds; combination group, $46.59 \pm 19.70$ seconds and negative control group, $222.97 \pm 48.84$ seconds. This shows that the fastest bleeding time was found in samples immersed in combination of binahong and soursop leaves extract and lowest bleeding time was found in negative control (distilled water) group. Data analysis was then followed by comparability test. This test was performed using Mann-Whitney $U$ test. Mann-Whitney $\mathrm{U}$ test results can be seen in table 2.

Post hoc test in the table shows the following results: mean bleeding time in binahong leaves extract group was not significantly different from that of soursop leaves extract group but was significantly different from that of combination group and distilled water group. Mean bleeding time in soursop leaves extract group was not significantly different from that of binahong leaves extract group but was significantly different from that of combination group and distilled water group. The mean bleeding time in the combination group was significantly different from that of binahong leaves extract group, 
Table 2 Mann-Whitney U Test

\begin{tabular}{lcc}
\hline Treatment groups & Bleeding time (mean \pm SD) & $\boldsymbol{p}$ Value \\
\hline Binahong extract & $65.70 \pm 20.61$ & \\
Soursop extract & $75.50 \pm 32.48$ & 0.650 \\
Binahong extract & $65.70 \pm 20.61$ & \\
Combination extract & $46.59 \pm 19.70$ & $0.049^{*}$ \\
Binahong extract & $65.70 \pm 20.61$ & \\
Distilled water (control) & $222.97 \pm 48.84$ & $0.000^{*}$ \\
Soursop extract & $75.50 \pm 32.48$ & \\
Combination extract & $46.59 \pm 19.70$ & $0.023^{*}$ \\
Soursop extract & $75.50 \pm 32.48$ & $0.000^{*}$ \\
Distilled water (control) & $222.97 \pm 48.84$ & \\
Combination extract & $46.59 \pm 19.70$ & $0.000^{*}$ \\
Distilled water (control) & $222.97 \pm 48.84$ & \\
\hline
\end{tabular}

*Mann-Whitney test; $\mathrm{p}<0.05$; significant

soursop leaves extract group, and distilled water group, and the mean bleeding time in distilled water group was significantly different from that of binahong leaves extract group, soursop leaves extract group and combination extract group.

\section{Discussion}

Based on the results of the study, it can be seen that in this group, hemostasis process runs naturally in the experimental mice, without the need for the use of any other hemostasis substances. The measurements of mean bleeding time in binahong leaves extract group and soursop leaves extract group showed no significant differences. In binahong leaves extract results suggest that binahong leaves extract and soursop leaves extract can effectively reduce the bleeding time of wound in the experimental mice. The measurements of mean bleeding times in combined extracts group compared with that of binahong leaves extract group, soursop leaves extract group and negative control group showed no significant differences, which means bleeding time in the combined extracts group has the lowest mean among other groups. This suggests that the combination of binahong leaves extract and soursop leaves extract was the most effective in reducing bleeding time of wound in mice too. Tannin is an astringent which gives a bitter taste when consumed. Tannins have very good effects for health and it can act as a vasoconstrictor through its astringent effect and accelerate protein release from cell and protein precipitation; precipitated protein is albumin. This protein precipitation process will induce the thromboxane A2 synthesis to increase platelet aggregation, thereby accelerating the formation of temporary platelet plugs in injured blood vessels. ${ }^{11}$ Flavonoids are also one of the chemical compounds found in binahong leaves and soursop leaves. Flavonoids play an important role in maintaining the permeability of blood vessels and increase the capillary vascular resistance. ${ }^{12}$ Flavonoids can also improve endothelial function by reducing oxidative stress. Good endothelial functions will impact on the activity of platelets, adhesion of leukocytes, and blood vessel muscle cell function. ${ }^{13}$ All the three treatment groups can reduce bleeding time significantly; it is evident from the $p$ value in each treatment group compared with the control group. Total levels of tannins and flavonoids in binahong and soursop leaves can affect hemostasis activities in extract preparation. Combination extract has higher tannin and flavonoid level; this is evident from the shortest mean bleeding time compared with the group that was given binahong leaves extract only or soursop leaves extract only. Reduction of bleeding time can also be caused by other compounds in binahong and soursop leaves that work in synergy with the tannins and flavonoids.

\section{Conclusion}

Binahong leaves extract combined with soursop leaves extract showed the best results compared with binahong leaves extract alone or soursop leaves extract alone for the hemostasis effect on cut wound in male mice. Further research is expected to pay more attention to equalization in the cutting measurements of mice tails to avoid bias in research. The research was conducted in mice; therefore, further research needs to be conducted using human subjects to ascertain the beneficial effects of these extracts on homeostasis in humans.

\section{Conflict of Interest}

The authors report no conflict of interest.

\section{References}

1. Yoneda T. Application of coenzyme Q10 for accelerating soft tissue wound healing after tooth extraction in rats. Nutrients 2014;6: 5756-5769.

2. Ardiana T, Kusuma ARP, Firdausy MD. Efektivitas pemberian gel binahong (andredera cordifolia) 5\% terhadap jumlah sel fibroblast pada soket pasca pencabutan gigi marmot (cavia cobaya). Odonto Dent J 2015;2: 64-70.

3. Gurcharan Singh, Novi Vicahyani Utami, Hermin Aminah Usman. Effect of Topical Application of Binahong (Anredera cordifolia (Ten.) Steenis) Leaf Paste in Wound Healing Process in Mice. AMJ 2014;1: 6-11.

4. Pedersen GW. Buku ajar praktis bedah mulut. Jakarta: EGC; 1996.

5. Majedi MA, Mahanani ES, Triswari D. Perbedaan efektivitas penambahan bubuk cangkang telur ayam ras dengan ayam kampung terhadap durasi perdarahan (in vivo). J Dent Insisiva 2013;2: 74-79. 
6. Yuliani SH, Fudholi A, Pramono S, et al. The effect of formula to physical properties of wound healing gel of ethanolic extract of binahong (anredera cordifolia (ten) steenis). IJPSR 2012;3: 4254-4259.

7. Tejdasulaksana R. Ekstrak etil asetat dan etanol daun sirih (piper betle 1.) dapat memperpendek waktu perdarahan mencit (mus musculus). J Kesehatan Gigi 2013;1: 32-39.

8. Muizuddin M, Zubaidah E. Studi aktivitas antibakteri kefir teh daun sirsak (annona muricata linn.) dari berbagai merk teh daun sirsak dipasaran. J Pangan dan Agroindustri 2015;3: 1662-1672.

9. Sumantri I, Hermawan GP, Laksono H. Ekstraksi daun sirsak (annona muricata 1) menggunakan pelarut etanol. J Farmasi 2012;2; 1-4.

10. Adri D. Aktivitas antioksidan dan sifat organoleptik teh daun sirsak (annona muricata linn.) berdasarkan variasi lama pengeringan. J Pangan dan Gizi 2013;4: 1-12.

11. Ashok PK, Upadhyaya K. Tannins are astringent. J Pharma Phytoc 2012;1: 45-50.
12. Aprinda D, Tantio E. Pengaruh pemberian ekstrak daun ungu (graptophyllum pictum (L) griff) terhadap waktu perdarahan (bleeding time) pada tikus wistar jantan. J Kesehatan Gigi 2014;2: 20-24.

13. Namal SSPJ. Green tea extract: chemistry, antioxidant properties and food applications-a review. J Funct Foods 2013;5: 1529-1541.

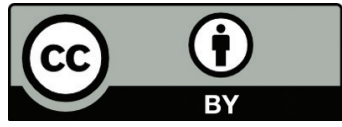

This work is licensed under a Creative Commons Attribution 